\title{
Groundwater Extraction in Floodplain Forests Reduces Radial Growth and Increases Summer Drought Sensitivity of Pedunculate Oak Trees (Quercus robur L.)
}

\author{
Georgios Skiadaresis*, Julia A. Schwarz and Jürgen Bauhus \\ Chair of Silviculture, Institute of Forest Sciences, University of Freiburg, Freiburg im Breisgau, Germany
}

In future, groundwater dependent ecosystems are likely to face increasing stress from direct and indirect effects of climate change. European floodplain forests already experience lower groundwater tables caused by river regulations and water extraction.

OPEN ACCESS

Edited by:

Barry Alan Gardiner,

European Forest Institute, Finland

Reviewed by:

Adriana Arango Velez,

Connecticut Agricultural Experiment

Station, United States

Tarin Toledo-Aceves,

Instituto de Ecología (INECOL), Mexico

*Correspondence:

Georgios Skiadaresis

georgios.skiadaresis@

waldbau.uni-freiburg.de

Specialty section: This article was submitted to

Forest Disturbance,

a section of the journal Frontiers in Forests and Global

Change

Received: 10 November 2018 Accepted: 25 February 2019

Published: 15 March 2019

Citation:

Skiadaresis G, Schwarz JA and Bauhus J (2019) Groundwater

Extraction in Floodplain Forests Reduces Radial Growth and Increases

Summer Drought Sensitivity of Pedunculate Oak Trees

(Quercus robur L.).

Front. For. Glob. Change 2:5, doi: 10.3389/ffgc.2019.00005
Yet, the effects of more frequent and prolonged dry and hot periods in combination with groundwater extraction on floodplain forests are not well-understood. Here, we conducted a dendroecological study in floodplain forests dominated by pedunculate oak (Quercus robur), a widespread forest type in Europe. Since drought-related precipitation deficits are increasingly less compensated by available groundwater, we hypothesized that groundwater extraction would increase climate sensitivity of growth. Moreover, we expected that younger trees that established under the condition of lowered groundwater tables would be less sensitive to droughts in contrast to older trees that might not be able to adapt to abrupt changes in groundwater levels. In three regions in the Upper Rhine Valley of Germany, we analyzed retrospectively tree-ring growth in Q. robur stands where (a) water extraction had dramatically lowered groundwater levels and trees presumably lost direct access to it, or (b) trees have not been affected by water extraction. In addition, (c) nearby sessile oak (Q. petraea) stands at upland sites were analyzed to isolate the climate signal for each study region from a groundwater signal. In total, we analyzed ring-width chronologies from 18 forest stands and investigated their relationship with climate. Radial growth of oak trees was strongly correlated with summer drought (SPEI, Standardized Precipitation Evapotranspiration Index). Their sensitivity to summer drought increased significantly following the onset of groundwater extraction (88-49 years ago). However, sensitivity of oaks to summer drought at sites with groundwater contact remained relatively stable over time. Oaks at sites without water extraction took advantage of favorable growing conditions. Our results show that access to groundwater can buffer negative effects of summer drought on tree growth. Therefore, in the face of the ongoing climate change and more frequent occurrence of extreme drought events, we recommend that groundwater extraction from floodplain forests should be reduced rather than increased to maintain tree vitality in the long term.

Keywords: climate change, climate-growth relationships, dendroecology, groundwater-fed forests, growth response, Rhine Valley 


\section{INTRODUCTION}

Groundwater is one of the most crucial and reliable freshwater resources of the planet. It provides water not only for human consumption, irrigation and industrial uses, but also for numerous ecosystems that depend either partly or exclusively on groundwater to cover their water needs (Bovolo et al., 2009; Orellana et al., 2012; Kløve et al., 2014). However, the quantity and quality of groundwater resources are globally at risk and are expected to be further affected by climate change in coming decades. The observed and projected changes in climate patterns will affect groundwater resources directly through temperature increases and alteration of precipitation regimes (i.e., amounts, forms and seasonal patterns) (Earman and Dettinger, 2011; Green et al., 2011). These direct effects of climate change on groundwater resources are highly uncertain (Taylor et al., 2013; Kløve et al., 2014). However, it is more certain that increasingly frequent and prolonged droughts will intensify groundwater appropriation for irrigation and industrial and domestic consumption (Bovolo et al., 2009; Earman and Dettinger, 2011; Green et al., 2011; Taylor et al., 2013; Kløve et al., 2014). This development will directly affect groundwater dependent ecosystems and amplify the negative effects of climate change on them (Kløve et al., 2014).

Floodplain forests are highly productive and biodiverse forest ecosystems that provide a variety of important ecological services including buffering of stream flow and improvement of water quality (Kozlowski, 2002; Schnitzler et al., 2005; Leuschner and Ellenberg, 2017). Trees in floodplain forests have access to both surface and groundwater to cover their water needs (Cunningham et al., 2011). This additional water resource can possibly explain the high productivity that has been commonly observed in floodplain forests (Cunningham et al., 2011). Alteration of groundwater regimes through water extraction and river regulations have been linked to reduced productivity and vitality and even to extensive dieback of floodplain forests (LeMaitre et al., 1999; Horner et al., 2009; Cunningham et al., 2011; Kath et al., 2014).

In Central Europe, the higher parts of hardwood floodplain forests are dominated by pedunculate oak (Quercus robur L.) (Leuschner and Ellenberg, 2017). Owing to their very fertile soils and the less frequent occurrence of floods, the majority of these forests have been converted to agricultural land in the last centuries (Hughes, 2003; Leuschner and Ellenberg, 2017). Remaining fragments of oak dominated floodplain forests in Europe are of crucial importance because of the multiple economic and ecological services they provide (Eaton et al., 2016; Leuschner and Ellenberg, 2017). However, extensive oak decline in recent decades across Europe has raised concerns about the future of these forests (Thomas et al., 2002; Thomas, 2008). A number of biotic and abiotic stressors are considered responsible for oak decline in Europe (Führer, 1998; Thomas, 2008). These include severe and repeated defoliation by insects, pathogen attacks, weather extremes such as droughts, severe winter and spring frosts, and decreased groundwater levels. Yet, extensive decline and mortality of oaks occurred in most cases only, when at least two stress factors interacted. However, as most of these factors are related to or controlled by climate, individual stress factors as well as their interactions should be examined (Führer, 1998; Thomas, 2008).

The study of tree-rings and hence radial growth of trees provides useful insights into changes of past growing conditions of forests and also facilitates investigations of short-term and long-term responses to abrupt and gradual changes in their environment. The influence of climatic variability is commonly examined as the relationship (i.e., correlation) between variation in annual stem-growth and climatic variables (hereafter referred to as "climate sensitivity"). The two most common oak species of Central Europe, pedunculate oak (Quercus robur L.) and sessile oak [Quercus petraea (Matt.) Liebl.] have been used extensively in dendrochronological studies (for a detailed review on the use of oaks in dendrochronology see the work by Haneca et al., 2009). Sensitivity of growth to drought has increased for both oak species in Central Europe over the last decades, but pedunculate oak appeared to be more sensitive to climatic variability than sessile oak (Friedrichs et al., 2008).

A complex interplay between groundwater availability and climatic variability controls tree growth in groundwater-fed forest ecosystems. However, the role of groundwater availability on tree responses to climatic fluctuations is poorly understood. To avoid or reduce negative impacts of increasing groundwater extraction in future, we need to understand how changes in groundwater availability affect the maintenance of forest structure and functioning (Zolfaghar et al., 2014). A number of studies have highlighted the importance of changes in groundwater regimes as a driver of oak decline and mortality (Thomas, 2008; Levanic et al., 2011; Stojanović et al., 2015). Other work has highlighted the role of groundwater availability for reducing the sensitivity of growth to climatic variability and especially to elevated summer temperatures for Abies balsamea and Pinus strobus growing in groundwater-fed wetlands in the North-eastern USA (Raney et al., 2016). However, most of these studies have focused on trees that were mature when groundwater levels dropped. To understand and predict responses of future oak generations to climate change and the associated decline in groundwater levels, a better understanding of tree-responses at different developmental stages is needed. It has been suggested that young tree-seedlings can adapt to a groundwater drawdown by extending their root systems to access water from deeper soil layers (Imada et al., 2008; Wang et al., 2015). However, the ability of trees to respond to changes in groundwater levels either by extending their roots to keep access to groundwater or by producing more roots in the upper soil layers is species-specific and might be related to the rate and extent of groundwater decline (Naumburg et al., 2005) and also to tree age. Previous studies on pedunculate oak indicated that old (more than 100 years old) in contrast to younger oaks $(<100$ years old) were not able to change their rooting pattern in response to lowered groundwater levels (Becker and Lévy, 1986; Thomas and Hartmann, 1998).

Although relationships between annual growth of pedunculate oak and climatic variables have been studied extensively, only few studies took into account additional changes in groundwater regimes. To our knowledge, no previous 


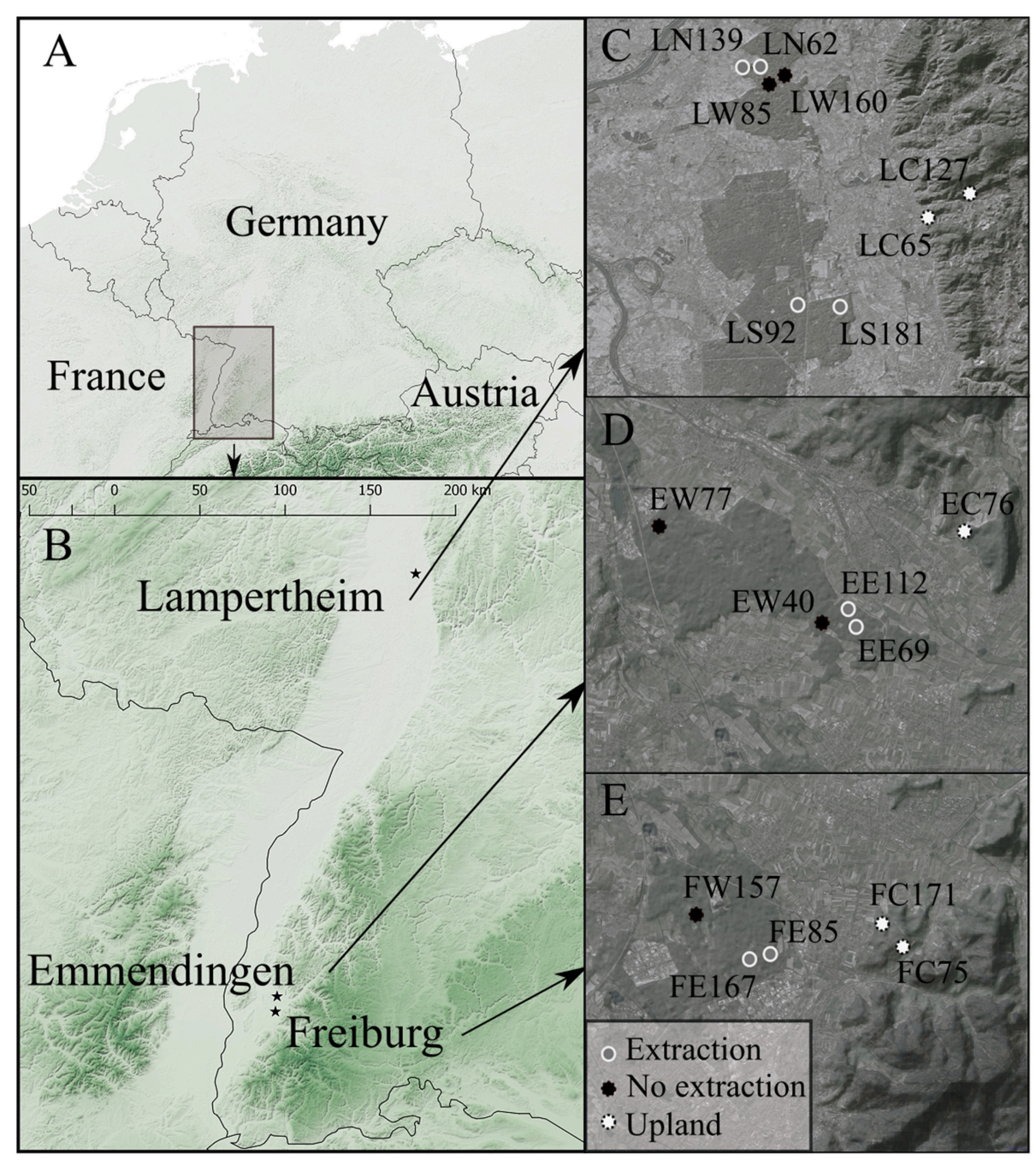

FIGURE 1 | Location of the study regions (A), the three study regions near Freiburg, Emmendingen, and Lampertheim (B), and locations of the investigated forest stands in each region (C, D and $\mathbf{E}$ for Lampertheim, Emmendingen and Freiburg, respectively). Stand IDs in (C-E) are acronyms denoting the study region and site type (first and second letter, respectively) of each investigated stand. F, E, L for Freiburg, Emmendingen, and Lampertheim, respectively. W indicates sites without groundwater extraction, $\mathrm{C}$ upland sites and $\mathrm{E}, \mathrm{S}$, and $\mathrm{N}$ are extraction sites ( $\mathrm{E}$ for the extraction sites in Emmendingen and Freiburg, $\mathrm{S}$ and $\mathrm{N}$ for the Southern and Northern extraction sites, respectively, in Lampertheim).Numbers in Stand IDs indicate the average tree age of each stand. The maps were created using the OpenLayers Plugin (Sourcepole, 2017) in QGIS (QGIS Development Team, 2017).

studies have investigated the effects of groundwater extraction on tree-growth sensitivity to climatic variability and especially to summer drought. Our overall aim for this study was to understand how lowered groundwater levels affect the sensitivity of growth to climate, in particular to summer droughts. We hypothesized that:

- Groundwater extraction increases climate sensitivity of tree growth because drought-related precipitation deficits are compensated by available groundwater to a lesser extent;

- The influence of lowered groundwater tables on climategrowth relationships is less pronounced in younger than in older trees, because young trees were established under the condition of water extraction and are therefore more likely to be adapted to the lowered water table.

\section{METHODS}

\section{Study Sites and Sampling Design}

Tree-ring growth in oak dominated forest stands was analyzed in three regions in south-western Germany (Figure 1). The investigated regions are located in the Upper Rhine Valley and situated in former floodplain areas. River regulations and human activities along the river Rhine, such as expansion of settlements, industrialization and intensification of agriculture, have significantly altered its hydrology, morphology, and water quality during the past centuries and caused marked changes in the surrounding ecosystems (Dister et al., 1990; van Dijk et al., 1995). One study region is located close to the city of Freiburg, where groundwater levels have been lowered since 1930 , initially due to river regulations and subsequently because 


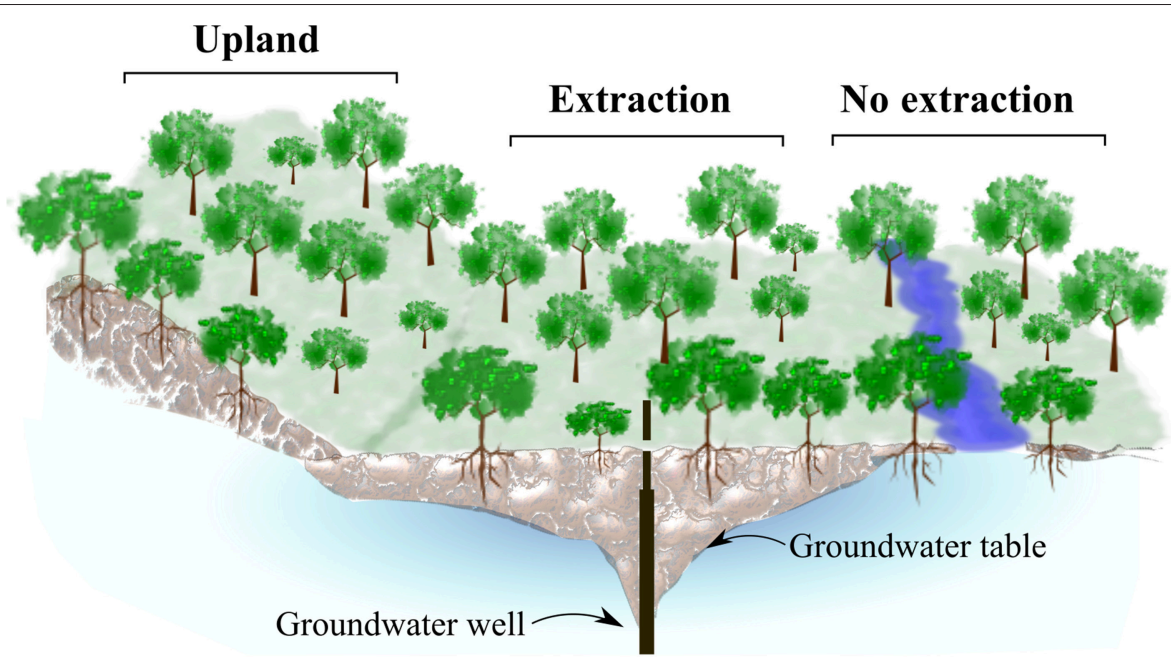

FIGURE 2 | Graphical representation of site-types in each study region. Oak stands from three different site-types with different groundwater conditions were sampled: Center, Quercus robur stands at sites adjacent to groundwater extraction wells, where trees have lost contact to groundwater (extraction sites), right, Q. robur stands at sites where trees have access to groundwater (no extraction sites) and left, upland Q. petraea stands, where trees never had contact to groundwater (upland sites).

of extraction for industrial uses. A second region is located $15 \mathrm{~km}$ north of Freiburg near the city of Emmendingen, where groundwater has been extracted for drinking water supply since 1961. The third region near Lampertheim is located approximately $200 \mathrm{~km}$ further north along the Upper Rhine Valley. There, massive extraction of groundwater from multiple wells within a forest area of approximately 10000 hectares has taken place since 1969. This has resulted in dramatic decreases in groundwater levels and decline in forest vitality (Ahner and Schmidt, 2011).

In each of the three study regions, we selected oak stands at sites with contrasting groundwater regimes (Figure 2). First, we identified forest stands located adjacent to groundwater extraction wells (extraction sites). Second, reference sites were identified, where no extraction has taken place. In all regions, these sites were located in close proximity to the extraction sites but closer to rivers and streams. Trees at these wetter sites (no extraction), have still access to groundwater at least seasonally. In addition, we included a third type of stands on drier uplands sites with free draining soils (upland sites). In all regions these upland stands were dominated by sessile oak, while the other two site types where dominated by pedunculate oak.

To analyse trees of different age at the onset of groundwater extraction, we selected young and old forest stands for each site type and region. Average stand age (in 2016) ranged from 62 to 181 years for the extraction sites, from 40 to 160 years for sites without extraction and from 65 to 171 years for the upland sites. At Lampertheim, we selected two extraction sites because of the large extent of the affected forest area. In the study regions near Freiburg and Emmendingen, we selected one stand without extraction and one upland stand, respectively, due to the lack of oak stands from different age-classes. Our study design resulted in a total of 18 sampled stands.

\section{Sampling and Dendrochronological Methods}

We selected 20 dominant or co-dominant trees per stand except in the LC65 stand in Lampertheim, where only nine trees could be sampled (Table 1). A total of 349 trees were sampled for the purposes of this study. To avoid spatial correlation within a stand, we chose trees that were no direct competitors. The minimum distance between the selected trees within each stand varied among stands depending on their age and size. On average, minimum distance between older trees was 15 and $10 \mathrm{~m}$ between individuals in the younger stands. At these distances we cannot rule out below-ground connections between sampled trees through root grafts.

First, we measured stem diameter at breast height (DBH at $1.3 \mathrm{~m}$ ) and the height of each target tree. Additionally, we assessed tree vitality based on the crown conditions of target trees as proposed by Roloff (2001). Vital trees with full crowns and vital fine twigs were assigned to crown class 0 ; trees assigned to class (1). showed first signs of crown degradation and twig abscission; trees of class (2). were noticeably weakened already; and seriously weakened and dying trees with dead main branches and disintegration of the entire crown were assigned to crown class (3). Selected trees covered all vigor classes present in the studied stands.

We extracted two cores per tree from opposite directions at $1.3 \mathrm{~m}$ stem height, using an increment-borer with $0.5 \mathrm{~mm}$ diameter (Haglöf, Sweden). At upland sites, where trees were growing on a slope, the two cores were taken perpendicular to the slope direction to avoid sampling of reaction wood. Subsequently, cores were air-dried and smoothed using progressively finer sandpaper to increase visibility of ring boundaries. Increment cores were scanned at 2,400 dpi using an Epson Expression 1649XL flatbed color image scanner. We 
TABLE 1 | Stand characteristics of the 18 stands from 3 study regions sampled in this study.

\begin{tabular}{|c|c|c|c|c|c|c|c|c|c|}
\hline Region & Site & Stand ID & $N$ trees & $\begin{array}{c}\text { Mean DBH } \\
\text { (and SD) in cm }\end{array}$ & $\begin{array}{l}\text { Mean height } \\
\text { (and SD) in m }\end{array}$ & $\begin{array}{l}\text { Elevation } \\
\quad \text { in } \mathrm{m}\end{array}$ & $\begin{array}{c}\text { Distance to } \\
\text { groundwater table in } \mathrm{m}\end{array}$ & $\begin{array}{l}\text { Mean age (and SD) } \\
2016 \text { in years }\end{array}$ & $\begin{array}{l}\text { Onset of } \\
\text { extraction }\end{array}$ \\
\hline \multirow[t]{5}{*}{ Emmendingen } & Extraction & EE69 & 20 & $32.4(5.6)$ & 26.1 (5.9) & 212 & 6 & $69(6)$ & 1961 \\
\hline & & EE112 & 20 & $54.2(10.7)$ & $27.8(5.4)$ & 212 & 6 & $112(6)$ & \\
\hline & Upland & EC76 & 20 & $51.4(8)$ & 32.1 (4.6) & 250 & - & $76(8)$ & \\
\hline & No extraction & EW77 & 20 & $52.2(5.8)$ & $26.11(3.2)$ & 197 & 2 & 77 (9) & \\
\hline & & EW40 & 20 & $32.2(5)$ & $23.4(3.9)$ & 206 & 1 & $40(6)$ & \\
\hline \multirow[t]{5}{*}{ Freiburg } & Extraction & FE85 & 20 & $52.1(7.1)$ & $31.3(3.5)$ & 237 & 25 & $85(7)$ & 1930 \\
\hline & & FE167 & 20 & $84.4(15)$ & $31(4.8)$ & 237 & 25 & $167(34)$ & \\
\hline & Upland & FC76 & 20 & $43.9(10)$ & $26.9(6.5)$ & 355 & - & 75 (12) & \\
\hline & & FC171 & 20 & 76.1 (10.8) & $34.4(5.8)$ & 305 & - & $171(42)$ & \\
\hline & No extraction & FW157 & 20 & 77.9 (14.3) & 29.6 (4.9) & 227 & 2 & $157(21)$ & \\
\hline \multirow[t]{8}{*}{ Lampertheim } & Extraction N & LN62 & 20 & 30.1 (5.9) & $19.2(2)$ & 99 & 6 & $62(5)$ & 1969 \\
\hline & & LN139 & 20 & $55.4(9.8)$ & $26.9(3.8)$ & 96 & 5.4 & 139 (10) & \\
\hline & Extraction S & LS92 & 20 & $29.6(5.4)$ & $20.9(3.2)$ & 98 & 5 & $92(9)$ & 1969 \\
\hline & & LS181 & 20 & $94.7(11)$ & 37.7 (4.8) & 100 & 6.5 & $181(8)$ & \\
\hline & Upland & LC65 & 9 & $37.4(4.8)$ & $28.5(4.7)$ & 246 & - & $65(6)$ & \\
\hline & & LC127 & 20 & $50.9(6.6)$ & $31.4(4.0)$ & 293 & - & $127(9)$ & \\
\hline & No extraction & LW85 & 20 & 38.9 (5.9) & $23.5(2.2)$ & 96 & 2 & 85 (12) & \\
\hline & & LW160 & 20 & 65.3 (11.9) & 34 (5.8) & 93 & 1.7 & $160(10)$ & \\
\hline
\end{tabular}

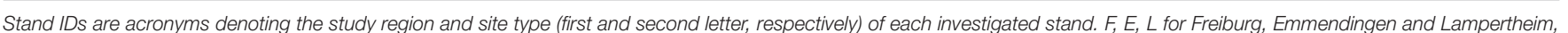

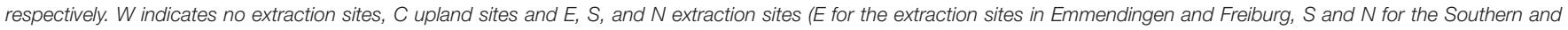
Northern extraction sites, respectively, in Lampertheim). Numbers in Stand IDs indicate the average tree age of each stand. SD, standard deviation.

used the WinDendro software (Regent instruments, Quebec) to measure tree-ring widths from the acquired pictures. The resulting tree-ring width series were visually and statistically crossdated using the functions corr.rwl.seg() and ccf.series.rwl() (Bunn, 2010) from the Dendrochronology Program Library $(d p l R)$ (Bunn, 2008) in R ( $\mathrm{R}$ Core Team, 2017). Prior to quantifying climate-growth relationships, age related trends were removed from the raw tree-ring series by using a 32-year spline with $50 \%$ frequency cut-off. This short spline removes the biological trends present in tree-ring series while simultaneously preserving annual to decadal variability in growth (Cook and Peters, 1981; Speer, 2001). Subsequently, the biweight robust mean was calculated to develop a residual chronology per stand. Stand-wise chronologies were truncated to have sample depth higher than five trees for each year to ensure adequate replicates for their whole length. Quality control, detrending and chronology development were performed using the $d p l R$ package in $\mathrm{R}$.

Several descriptive statistics were calculated to assess the quality of raw (ar1) and detrended (Mglk, EPS, Rbar, ar1) chronologies for each stand. First order autocorrelation (ar1) was used to assess how current year's growth was affected by growth in the previous year (Fritts, 1976; Speer, 2010). Mean gleichläufigkeit (synchronicity) (Mglk) was used to assess similarity of detrended tree-ring series among trees from each stand (Schweingruber, 1988). The $g \mathrm{lk}()$ function from the $d p l R$ package was used to compute glk (gleichläufigkeit) which performs pairwise comparison of all possible combinations between series within each stand. The expressed population signal (EPS) is an indicator of how well a chronology represents a theoretical infinite population (Wigley et al., 1984; Buras, 2017). It is used as an indicator of the common variability in detrended chronologies. Low values of EPS (commonly $<0.85$ ) indicate that the chronologies are dominated by individual tree signals rather than a consistent stand-level signal (Speer, 2010). Rbar is the mean correlation between tree-ring series within a stand. The Rbar was used as a measure of the common signal strength of the detrended chronologies.

\section{Climate Data}

Monthly temperature and precipitation data for each study region were obtained from the Climate Data Center of the German Weather Service (Deutscher Wetterdienst) using the meteorological stations closest to the study sites (Supplementary S.1). The distances between the selected meteorological stations and study sites were $<20 \mathrm{~km}$. For sites in the regions of Freiburg and Emmendingen, data from one station were used because the two sites are located within $10 \mathrm{~km}$ from the selected station. In Lampertheim, two weather stations were selected, one station for the extraction site in the northern part of the region and the no-extraction site and another one for the extraction site in the southern part and the upland site. For the sites in the regions of Freiburg and Emmendingen, climate data were obtained for the period between 1921 and 2016. For the study region near Lampertheim, climate data were obtained for the two sites in the northern part of the region for the period between 1896 and 2016 while for the sites in the southern part, data for the period between 1890 and 2016 were available. Due to 
the similarity (correlation coefficient for monthly precipitation and temperature series from the two stations were 0.9 and 1.0, respectively) and close proximity $(25 \mathrm{~km})$ of the two stations in the region of Lampertheim, climate data from the two stations were averaged over the common period (1896-2016) for all subsequent trend analysis. Temporal trends in seasonal precipitation and temperature were quantified and tested for significance by performing Mann-Kendall tests (Mann, 1945) using the Kendall package in R (McLeod, 2011). Rates of change per year were estimated by calculating non-parametric Sen's slopes (Sen, 1968) using the trend package in R (Pohlert, 2018).

Based on the obtained precipitation and temperature data, we calculated the Standardized Precipitation Evapotranspiration Index (SPEI) (Vicente-Serrano et al., 2010) using the SPEI package in R (Vicente-Serrano et al., 2010). Different periods (6, 12,24 , and 36 months) of the SPEI index were calculated for the months of the vegetation period (from March to September). Additionally, seasonal means for different scales of monthly SPEI values were calculated for the whole vegetation period and for individual seasons: spring (March, April, and May), summer (June, July, and August), autumn (September, October, and November), and winter (December of previous year, January, and February). We chose the multi-scalar SPEI index because previous studies have highlighted its superior performance in assessing drought impacts on ecological and hydrological systems and especially in predicting changes in forest growth (VicenteSerrano et al., 2012, 2013; Bhuyan et al., 2017).

\section{Statistical Analysis \\ Overall Climate-Growth Relationships}

Overall climate-growth relationships were assessed by calculating bootstrapped Pearson's correlation coefficients from the detrended tree-ring chronologies and monthly and seasonal climatic data, using the package treeclim in R (Zang and Biondi, 2015). We first calculated correlation functions for the separate months of the vegetation period, from March to September, and then seasonal means for spring, summer, autumn, winter as well as for the whole vegetation period. Monthly and seasonal means were calculated for temperature, precipitation and the different periods of the standardized precipitation evapotranspiration index (SPEI). Coefficients of correlation between the stand-specific chronologies and climatic variables were averaged for each month and season, first including all stands, and subsequently separately for the different sites. To obtain average correlation coefficients, we transformed the correlation coefficients for the separate chronologies to Fisher's $z$ scores prior to averaging and then back-transformed them to Pearson's correlation coefficients. This was done because the back-transformed average $z$ score was found to be less biased than simply averaging correlation coefficients (Silver and Dunlap, 1987).

\section{Temporal Development of Climate-Growth Relationships}

To investigate the temporal variation of climate-growth relationships, we calculated bootstrapped moving correlation functions. These were calculated for consecutive 30-year windows, which were moved progressively by 1 year. Initially, moving correlation functions were calculated separately for all stand chronologies and monthly and seasonal climatic data as described above for the static correlation functions. To identify and better demonstrate changes related to groundwater extraction, correlation coefficients were presented relative to the date when the extraction of groundwater began (date when the extraction began $=0$ ) for all sites within each of the three regions. Each correlation coefficient for a year $\mathrm{x}$ is the correlation coefficient between a tree-ring chronology and the specific climatic variable for the 30-year time window starting in the year $\mathrm{x}$ (time period starting in year $\mathrm{x}$ until year $\mathrm{x}+30$ ).

Although we computed moving correlation functions for all climatic variables mentioned above (temperature, precipitation and different scales of SPEI), results presented and discussion are focused on the shorter time-scale of SPEI (6 months), since it was found to correlate best with growth of oaks at all the investigated sites. The calculation of both overall (static) and moving correlations for each of the 18 stands was performed for the maximum period during which climate and growth data overlapped (41-120 years).

\section{Radial Stem-Growth Responses to Dry and Wet Summers}

To properly interpret possible differences in sensitivity of annual stem growth to summer drought among trees from sites with differing groundwater regimes, we quantified growth responses for both dry and wet summer conditions. This was done by calculating absolute growth changes (radial growth in year $t$ minus radial growth in year $t-1$ ) for individual trees excluding the first 20 years of juvenile growth and the time period before the onset of groundwater extraction. Years were characterized as dry or wet based on the mean SPEI 6 of the three summer months (June to August). Years with SPEI 6 values below -1 were characterized as dry, while years with values $>1$ were characterized as wet. We tested for differences in growth responses to dry and wet summer conditions among trees at sites with differing groundwater regimes through nonparametric Kruskal-Wallis tests. Trees from sites with similar groundwater conditions were pooled across the three study regions. Afterwards, we used Wilcoxon sign tests to perform pairwise comparisons among the three different sites (extraction, no extraction, and upland).

\section{RESULTS}

\section{Tree Ring Data, Chronology Characteristics, and Statistics}

The descriptive statistics calculated for the different stands indicate an overall good quality of the developed chronologies (Table 2 and Supplementary S.2, S.3). Mean annual radial growth of the sampled trees ranged from 1.26 to $3.29 \mathrm{~mm}$ per year, where trees in the younger stands $(<100$ years old $)$ had higher mean increments than older ones (more than 100 years old) at the majority of sites. This is in line with expected age-related decreasing growth trends. Annual growth of trees at the sites without groundwater extraction was higher than 
TABLE 2 | Summary statistics of the 18 stand chronologies.

\begin{tabular}{|c|c|c|c|c|c|c|c|c|c|c|}
\hline Stand ID & Site & Mean (mm) & Stdev & Time span & Length (years) & ar1 & Mglk $^{\star}$ & EPS $^{\star}$ & Rbar $^{\star}$ & $\operatorname{ar1}^{\star}$ \\
\hline EC76 & Upland & 2.78 & 0.43 & 1937-2016 & 80 & 0.32 & 0.67 & 0.91 & 0.34 & -0.03 \\
\hline EE69 & Extraction & 1.99 & 0.57 & 1943-2016 & 74 & 0.50 & 0.69 & 0.94 & 0.43 & -0.03 \\
\hline EE112 & Extraction & 1.97 & 0.43 & 1900-2016 & 117 & 0.52 & 0.66 & 0.94 & 0.43 & 0.32 \\
\hline EW40 & No extraction & 3.29 & 1.14 & 1976-2016 & 41 & 0.70 & 0.63 & 0.95 & 0.49 & 0.45 \\
\hline EW77 & No extraction & 2.91 & 0.77 & 1939-2017 & 79 & 0.50 & 0.73 & 0.96 & 0.53 & 0.26 \\
\hline FE85 & Extraction & 2.45 & 1.03 & 1927-2016 & 90 & 0.77 & 0.69 & 0.95 & 0.49 & 0.17 \\
\hline FE167 & Extraction & 1.95 & 0.54 & 1824-2016 & 193 & 0.71 & 0.63 & 0.90 & 0.31 & 0.25 \\
\hline FC75 & Upland & 2.44 & 0.57 & 1931-2016 & 86 & 0.68 & 0.62 & 0.92 & 0.36 & 0.32 \\
\hline FC171 & Upland & 1.67 & 0.48 & 1808-2016 & 209 & 0.69 & 0.65 & 0.93 & 0.41 & 0.35 \\
\hline FW157 & No extraction & 2.04 & 0.64 & 1846-2016 & 171 & 0.74 & 0.65 & 0.93 & 0.41 & 0.35 \\
\hline LC65 & Upland & 2.20 & 0.77 & 1955-2016 & 62 & 0.76 & 0.65 & 0.84 & 0.37 & 0.36 \\
\hline LC127 & Upland & 1.65 & 0.41 & 1886-2016 & 131 & 0.65 & 0.69 & 0.94 & 0.44 & 0.46 \\
\hline LN62 & Extraction & 1.95 & 0.69 & 1953-2016 & 64 & 0.61 & 0.70 & 0.96 & 0.53 & 0.38 \\
\hline LN139 & Extraction & 1.62 & 0.44 & 1874-2016 & 143 & 0.40 & 0.74 & 0.97 & 0.61 & 0.18 \\
\hline LS92 & Extraction & 1.26 & 0.49 & 1921-2016 & 96 & 0.85 & 0.65 & 0.94 & 0.43 & 0.57 \\
\hline LS181 & Extraction & 2.13 & 0.63 & 1829-2016 & 188 & 0.80 & 0.66 & 0.93 & 0.42 & 0.29 \\
\hline LW85 & No extraction & 1.91 & 0.55 & 1921-2016 & 96 & 0.68 & 0.64 & 0.94 & 0.43 & 0.43 \\
\hline LW160 & No extraction & 1.70 & 0.36 & 1851-2016 & 166 & 0.47 & 0.66 & 0.93 & 0.42 & 0.27 \\
\hline
\end{tabular}

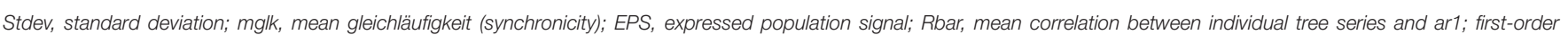

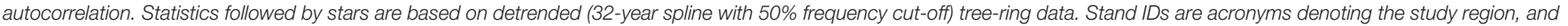

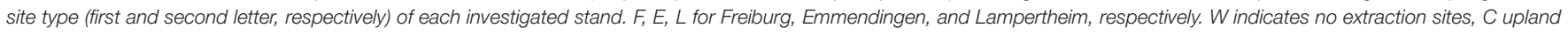

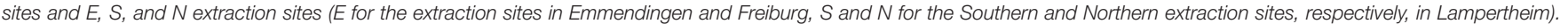
Numbers in Stand IDs indicate the average tree age of each stand.

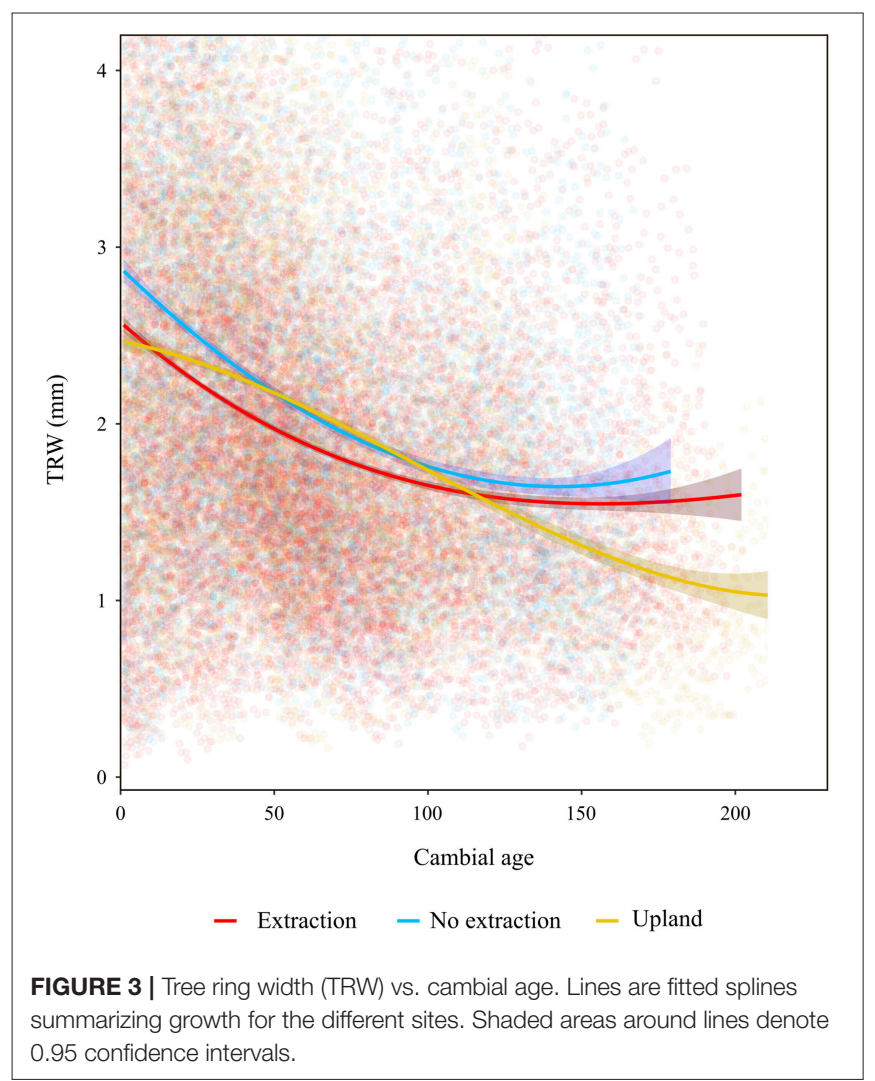

that of oaks from extraction sites over the entire range of cambial ages (Figure 3). Growth of sessile oaks at the upland sites was comparable to that of oaks at sites without extraction for cambial ages $<100$ years old. However, annual growth of trees at upland sites was lower than that of trees at the extraction and no extraction sites for cambial ages more than 100 years old. Series lengths of the developed chronologies were highly variable (ranging from 41 to 209 years) (Table 2 and Supplementary S.2). These differences were attributable to the different calendar years when groundwater extraction started in the three study regions.

\section{Climate Trends}

Over the last 100 years, there was a steady and significant $(p<0.05)$ increase in mean temperature of all seasons and in all regions (on average $0.2^{\circ} \mathrm{C}$ per decade for the regions of Freiburg and Emmendingen, and $0.1^{\circ} \mathrm{C}$ per decade for the region of Lampertheim), except for winter temperature in the Lampertheim region, where the trend was not statistically significant (Figures 4A,B and Supplementary S.4). In contrast, the trends in precipitation were less consistent and varied among seasons and between the southern regions (Emmendingen and Freiburg) and the northern region (Lampertheim). For the southern regions, summer precipitation tended to decrease over the last 100 years $(p=0.06)$, while in the same region, mean precipitation in winter, spring and autumn showed no particular trends (Figure 4C and Supplementary S.4). Surprisingly, winter and spring precipitation in the region of Lampertheim showed a 

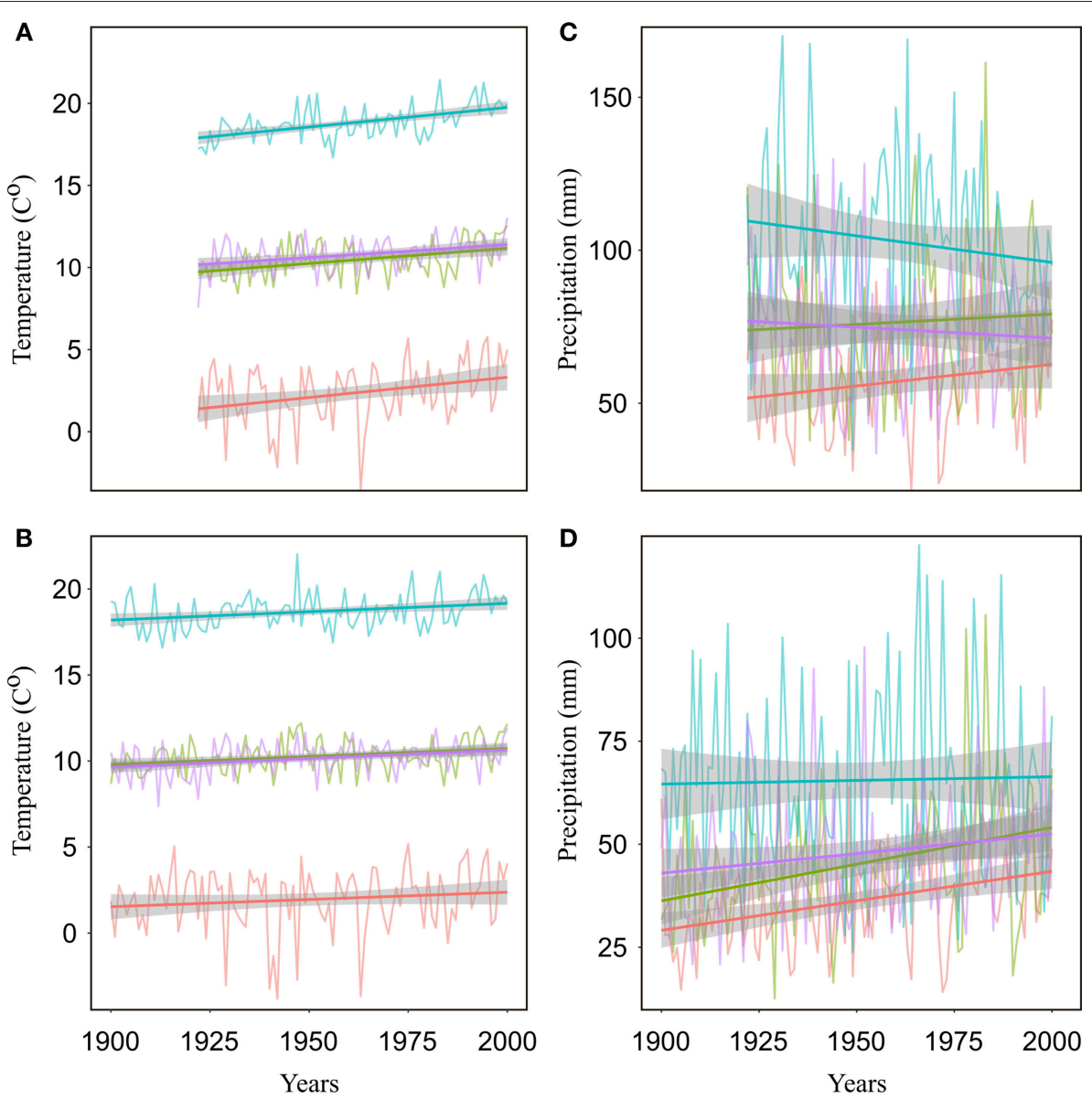

Seasons:

- Winter - Spring - Summer - Autumn

FIGURE 4 | Seasonal temperature and precipitation with trend lines (regression lines) for the investigated regions: (A) seasonal mean temperatures for Freiburg and Emmendingen, (B) seasonal mean temperatures for Lampertheim, (C) seasonal mean precipitation for Freiburg and Emmendingen, and (D) seasonal mean precipitation of Lampertheim. Winter includes previous year December to February of current year; spring = the months from March to May; summer season includes the months June to August and autumn the months from September to November. Gray areas denote 0.95 confidence intervals.

significantly positive trend during the examined period $(p<0.05$, Figure 4D and Supplementary S.4).

\section{Climate-Growth Relationships}

We assessed responses of tree growth to climatic variability by computing bootstrapped correlation functions between the stand-wise chronologies and the different monthly and seasonal climatic variables (precipitation, temperature and three different scales of the SPEI drought index). The SPEI series, both calculated for separate months and seasons, were better indicators of the growth responses of all investigated forest stands compared to precipitation or temperature series alone (lower growth was associated with more negative SPEI values) (Figure 5). Among all calculated SPEI-series, those referring to a shorter time-scale of 6 consecutive months, correlated best with inter-annual tree-growth variations across the different stands. Overall, growth of oaks in the investigated stands seemed to be strongly associated with summer drought as indicated by the highest positive correlation of growth data with SPEI 6 ending in July of the current year and mean SPEI 6 of the three summer months (June to August). These two SPEI indices showed significant correlations with growth series for 17 out of the 18 sampled stands (Figure 5). Further, a positive and significant correlation was found between radial growth and SPEI 6 of June of the current year for all 18 stands. The longer periods of SPEI showed in almost all cases fewer and weaker correlations with annual growth compared to those found for SPEI 6.

With a few exceptions, we found no significant relationship between tree growth and temperature across the studied stands (Figure 5). However, it appears that precipitation played a more important role for tree growth than temperature, as indicated by the stronger and higher number of significant correlations (Figure 5). Most importantly, mean monthly sums of precipitation during the vegetation period were strongly correlated with growth series for 12 out of the 18 sampled stands. 


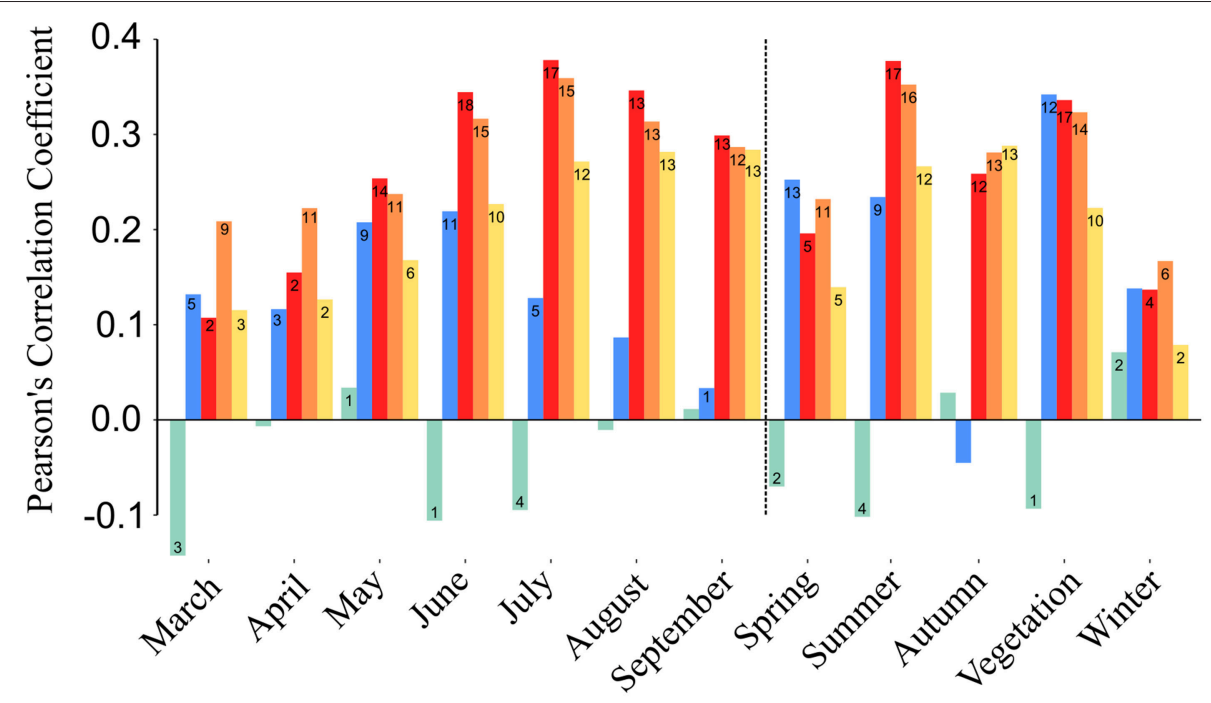

Climate variables:

\section{Temperature Precipitation $\square$ SPEI $6 \square$ SPEI $12 \square$ SPEI 24}

FIGURE 5 | Averaged Pearson's correlation coefficients of all 18 detrended stand-wise growth chronologies with mean temperature, precipitation sums and three different scales of the Standardized Precipitation Evapotranspiration Index (SPEI) (6, 12, and 24 months). The vertical dashed line separates monthly from seasonal correlations. Seasonal means are calculated for spring (March to May), summer (June to August), autumn (September to November), winter (previous year December to February) as well as for the vegetation period (from March to September). The figures within bars indicate the numbers of stands with statistically significant correlations (maximum 18).

Climate-growth relationships for the individual stands and site-types (related to groundwater situation) were investigated for SPEI 6, as this climatic parameter was best associated with growth in the sampled stands regardless of age and site conditions (Figure 5). Correlations of tree-ring chronologies with SPEI 6 series ending in the months May to September and with mean seasonal SPEI 6 series for summer (June to August) and the whole vegetation period (May to September) were positive and significant for all site types (Figure 6). Drought during the summer months seemed to play the most important role in controlling tree growth, in particular for the lowland sites (sites with and without extraction), where correlations between annual growth and SPEI 6 series were stronger than at the upland sites (Figure 6).

Remarkably, the strongest correlations between tree-growth and SPEI 6 were observed for trees growing at sites without groundwater extraction followed by trees from the extraction sites while the lowest correlations were found for trees from the upland sites (Figure 6C). For trees from sites without extraction, the strength of the relationship between growth and SPEI 6 during the summer months as well as during the vegetation period tended to decrease with average stand age (Figure 7B). On the other hand, no such trends could be observed at the extraction (Figure 7A) and upland sites (Figure 7C).

In addition, trees at sites without groundwater extraction showed significantly higher growth increases in years with favorable summer conditions (SPEI 6 of summer months $>1$ ) $(p<0.01)$ compared to trees at the extraction and upland sites (Figure 8). However, in years with adverse summer conditions
(SPEI 6 of summer months $<-1$ ), trees from the different site types showed more similar growth responses. Here, trees at the no extraction sites had slightly (although statistically not significant) stronger growth depressions than trees at the extraction and upland sites (Figure 8).

\section{Temporal Variability in Climate-Growth Relationships}

Temporal changes in sensitivity of radial growth to climate were assessed by computing moving-window correlation functions between the detrended stand-wise chronologies and climatic variables (precipitation, temperature and three different scales of SPEI index). Moving correlation analyses revealed a general instability and an overall strengthening of the relationship between growth and SPEI 6 over time for the investigated period (Figures 9, 10). Interestingly, this increasing sensitivity of tree-growth to drought was interrupted for the 30year long windows starting between 1920 and 1950, at all sites (Supplementary S.5).

\section{Temporal Variability in Growth Sensitivity to Drought at the Extraction Sites}

The strength of the relationship between tree-growth and monthly and seasonal values of SPEI 6 during the vegetation period at the extraction sites has been increasing over the last decades, indicating a higher growth sensitivity to seasonal and in particular to summer droughts (Figures 9, 10). This is highlighted not only by the more positive values of correlation coefficients, but also by the larger number of significant 

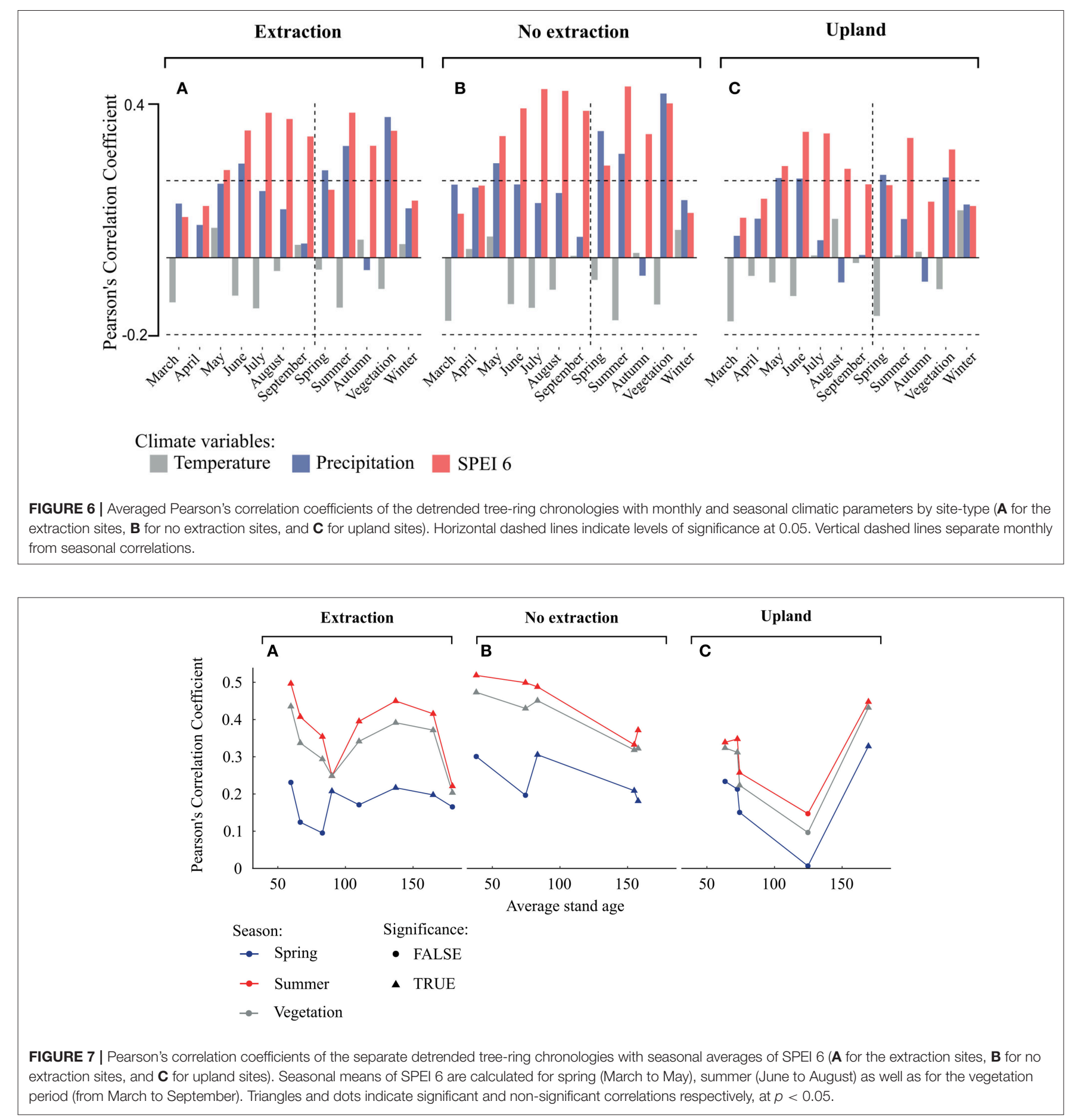

correlations over time (Figures 9, 10). For each of the stands at extraction sites, the increase in growth sensitivity to monthly and seasonal values of SPEI 6 becomes especially apparent soon after the onset of groundwater extraction (i.e., as soon as the 30-year long windows approach the extraction date "0"). This is indicated by the much higher proportion of significant correlation coefficients in the post-compared to pre-extraction period (Figures 9, 10).

\section{Temporal Variability in Growth Sensitivity to Drought at the Upland Sites}

The correlation between growth and SPEI 6 was weaker for sessile oaks growing in the drier upland stands compared to pendunculate oaks at lowland sites (extraction and no extraction) for the regions of Emmendingen and Lampertheim. In contrast, correlation coefficients of trees growing in upland stands in Freiburg were more similar to those of trees from the lowland 


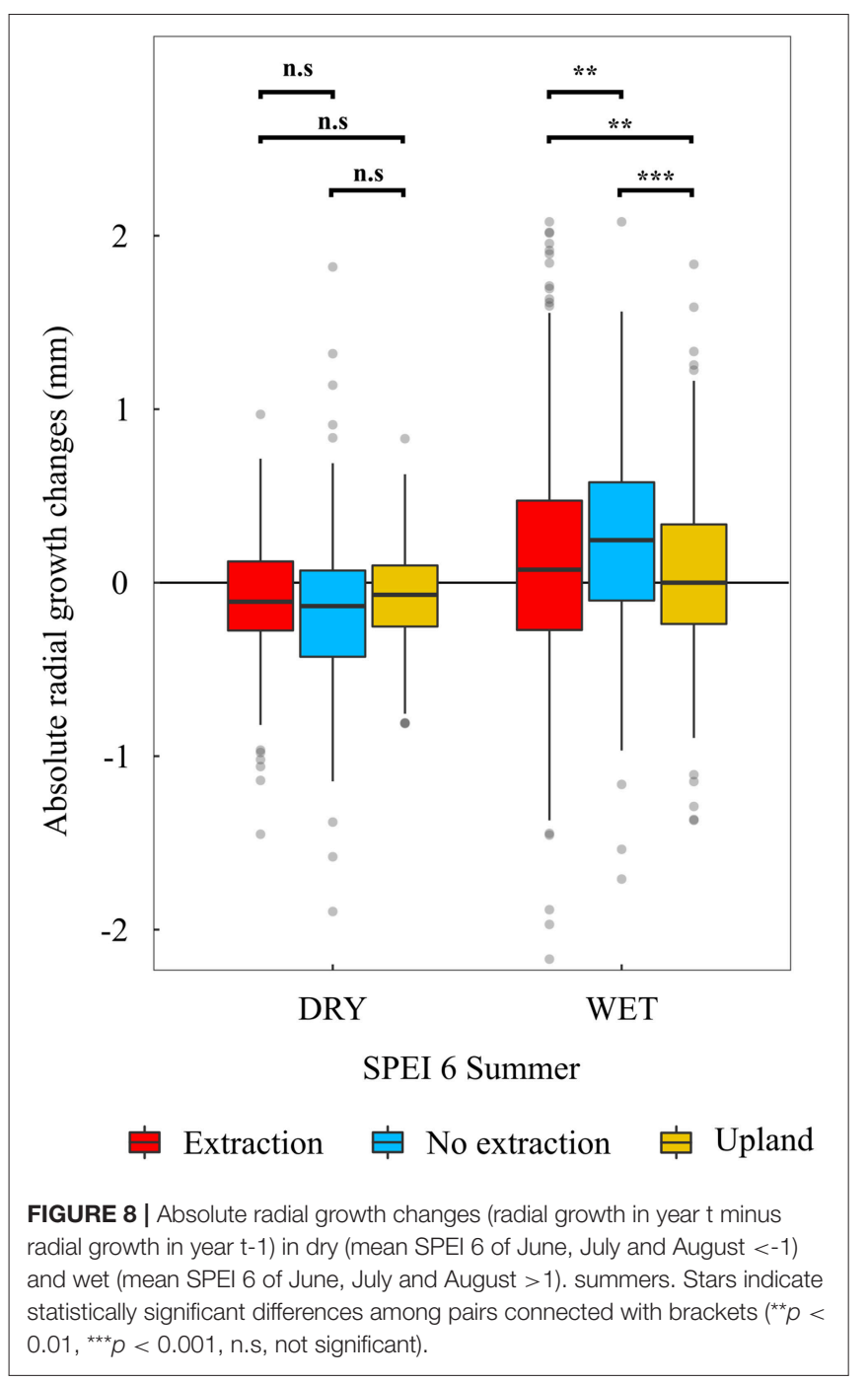

sites in this region (Figure 9). Remarkably, in the first half of the investigated period, there were only very few significant drought-growth relationships for upland stands in the regions of Lampertheim and Emmendingen (Figure 9). However, similar to the results of the extraction sites, sensitivity of growth to drought during the vegetation period increased over the last decades when combining data from all upland sites (Figure 10C).

\section{Temporal Variability in Growth Sensitivity to Drought at the No Extraction Sites}

In contrast to extraction and upland sites following the period of lower sensitivity of tree growth to drought (1920-1950), correlation coefficients at sites without extraction reached the previous levels and did not exceed them as it did at the extraction and upland sites (Figures 9, 10 and Supplementary S.5). Interestingly, there was no drop in the correlation coefficients at the site without extraction in Emmendingen (stand ID = EW77, Figure 9B) during this period. Here the overall correlation coefficients remained stable and higher than in stands from the other two regions (Freiburg and Lampertheim). These differences might be attributable to the younger age of stands at the no extraction site in the region of Emmendingen (see also Table 1).

\section{DISCUSSION}

Our study design (Figure 2) facilitated the investigation and direct comparison of climate-growth relationships of trees growing under differing groundwater regimes. We were able to quantify the development of climate-growth relationships over approximately the past 100 years including for trees that have been exposed to lowered groundwater levels for several decades (49-88 years). The findings of this study support the idea that changes in groundwater levels can modify climate-growth relationships in groundwater-dependent forest ecosystems. Contrary to our expectation, there appeared to be no consistent relationship between tree age and radial growth sensitivity to climatic variability across sites with differing in soil water regime.

\section{Climatic Sensitivity of Radial Growth in Oaks}

The positive correlations between growth of oaks and the seasonal SPEI 6 for summer (i.e., the average SPEI 6 of June, July, and August) (Figures 5, 6) suggest that drought severity during summer but also during the first months of the current vegetation period control growth. This was found for all three investigated regions and regardless of distance to groundwater table or stand age. The observed higher sensitivity of both oak species to short-term drought stress and especially during summer months is consistent with other findings from studies across Europe (Drobyshev et al., 2008; Mérian et al., 2011; Bhuyan et al., 2017; Árvai et al., 2018) including observations from Central-West Germany (Friedrichs et al., 2008). However, sessile oaks in the drier uplands showed an overall lower sensitivity to climatic parameters compared to pedunculate oaks at the lowland sites (with and without extraction) (Figure 6C). In addition, trees at upland sites were indeed less responsive to both favorable and unfavorable summer conditions (Figure 8). This difference between upland and lowland sites might be attributable to species-specific climatic sensitivity, as earlier studies report higher climatic sensitivity for pedunculate than sessile oaks (Friedrichs et al., 2008).

Several studies suggest that inter-annual variation observed in tree-ring widths of pedunculate and sessile oaks is largely related to the variability of latewood width and to a lesser extent to that of earlywood width (Zhang, 1997; González and Eckstein, 2003; Kern et al., 2013). The strong relationship between climatic conditions in summer (June to August) and radial growth that we observed here for both oak species may be explained by the strong dependence of latewood formation on water availability during these months (González and Eckstein, 2003). Similar relationships can be expected in other ringporous species (see for example Zhang, 1997; González and Eckstein, 2003 and references therein). In addition, our results indicate that precipitation during the vegetation period (March 

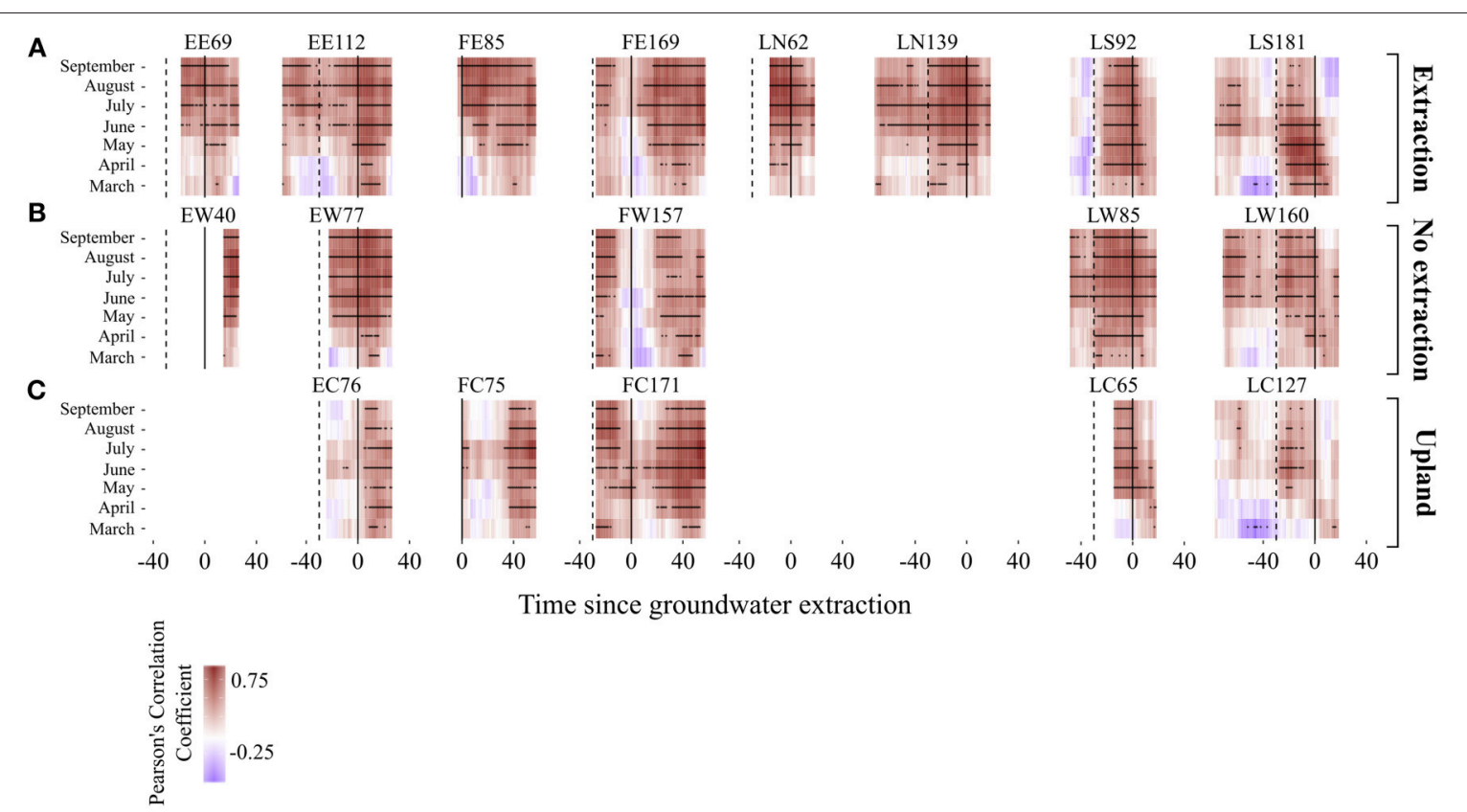

Time since groundwater extraction

FIGURE 9 | Moving correlations between monthly and mean seasonal values of SPEl 6 and growth for the different oak stands. (A for the extraction sites, B for no extraction sites, and $\mathbf{C}$ for upland sites). The window length is 30 years and the window offset is 1 year. Black stars indicate significance at $p<0.05$. The continuous vertical lines indicate the starting date of the extraction. The dashed lines are placed 30 years before the extraction started. Note that correlation coefficients are presented here relative to the date when the extraction of groundwater began (date when the extraction began $=0$ ). Time since extraction indicates the beginning of each 30-year window. For instance, correlation coefficient in year $\mathrm{x}$ is the correlation coefficient between growth and the specific climate parameter for the 30-year period starting in year $x$. Stand IDs are acronyms denoting the study region and site type (first and second letter, respectively) of each investigated stand. F, E, L for Freiburg, Emmendingen and Lampertheim, respectively. W indicates no extraction sites, $C$ upland sites and $E, S$, and $N$ extraction sites ( $E$ for the extraction sites in Emmendingen and Freiburg, $\mathrm{S}$ and $\mathrm{N}$ for the Southern and Northern extraction sites, respectively, in Lampertheim). Numbers in Stand IDs indicate the average tree age of each stand.

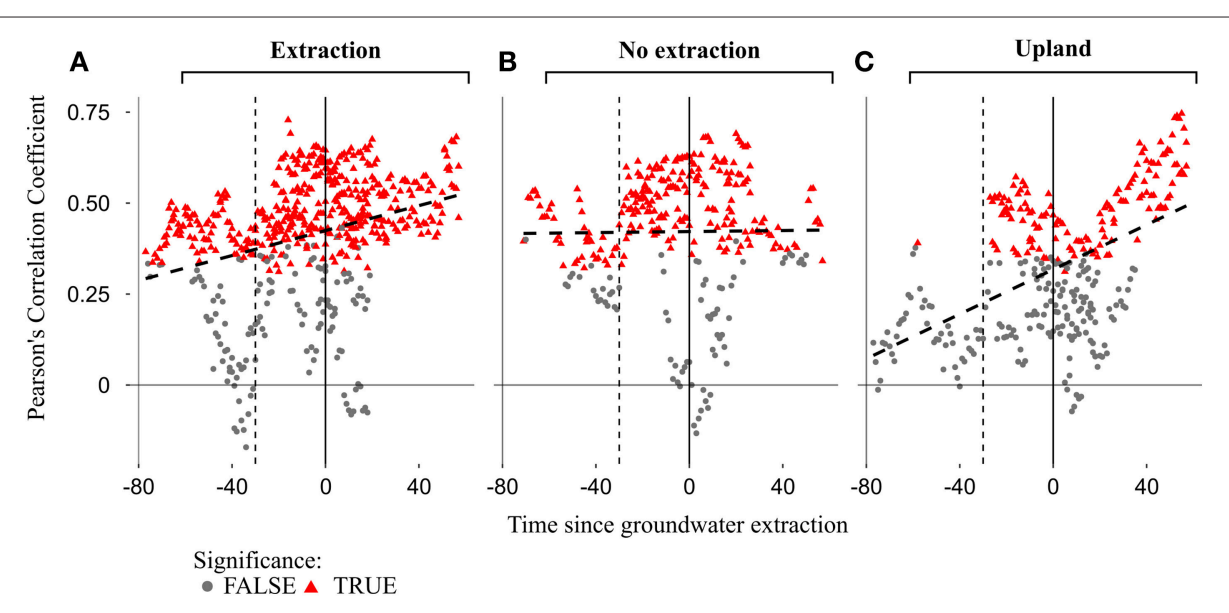

FIGURE 10 | Moving bootstrapped correlations between annual growth and mean SPEI 6 of summer months (June to August) for the three different site-types [extraction (A), no extraction (B), and upland (C)]. Red triangles and gray dots indicate significant and non-significant correlations respectively, at $p<0.05$. Each point represents the correlation coefficient of a single stand calculated for a 30-year-long window. Time on the x-axis represents the starting year of each 30 -year-long window, which is relative to the beginning of the extraction (extraction date set to 0 ) due to different onsets of extraction among regions. Solid vertical lines indicate the dates when the extraction of groundwater began, while the dashed lines mark 30 years before the onset of groundwater extraction.

to September) plays an important role in controlling oak growth while temperature seems to have a comparably lower impact on growth of the studied trees. Similarly, higher growth sensitivity to drought (Palmer Drought Severity Index, PDSI) and precipitation than to temperature has been reported for oaks sampled within a large network of sites in the same region (Friedrichs et al., 2008) and for north-eastern Hungary (Kern et al., 2013). 


\section{The Influence of Tree Age on Growth Sensitivity in Oaks}

Sensitivity of oaks to climatic variability at sites without groundwater extraction appeared to decrease with stand age, whereas no clear trend occurred at the other site types (Figure 7). Previous studies have yielded contradictory results concerning the effect of age on climatic sensitivity of trees (e.g., Rozas, 2005; Rozas et al., 2009; Copenheaver et al., 2011; Voelker, 2011; Konter et al., 2016). Any age-related effects have been attributed to stand dynamics and/or physiological and morphological changes with tree development (Day et al., 2002). With increasing age and height, water is transferred over longer distances within trees, which requires adjustments of water conducting elements (Ryan et al., 2006). For example, vessel size increased with cambial age in ring-porous oak species (e.g., Rita et al., 2016). However, increases in conduit diameter can render trees more susceptible to drought-induced cavitation, potentially increasing the susceptibility of older trees to drought (Ryan et al., 2006; Fonti et al., 2010; Voelker, 2011). From our data, we cannot explain why climate sensitivity of tree-growth at sites without water extraction was lower in older than in younger trees. A possible explanation could be that large trees which can store more non-structural $\mathrm{C}$ may be able to support radial growth to a larger extent from these reserves and are therefore less reliant on the actual climatic conditions (Galiano et al., 2011; Sala et al., 2012).

Interestingly, growth sensitivity to climatic variables in trees at sites without groundwater extraction was on average higher than in trees at the extraction and upland sites (Figures 6, 7). It may be that the comparably high groundwater tables during most months of the year cause oak trees to develop a relatively shallow root system, which in turn could have led to an increased sensitivity to summer drought as water availability in the upper soil becomes limited (Oosterbaan and Nabuurs, 1991; Leuschner and Ellenberg, 2017). Indeed, growth of trees at the sites without water extraction was most responsive to both wet and dry summers, demonstrating a higher ability of these trees to take advantage of favorable summer conditions but also slightly stronger growth depressions during periods of reduced soil water availability (Figure 8). However, annual growth of trees at sites without groundwater extraction was superior to that of trees at the extraction sites (Figure 3 and Table 2). This indicates that negative effects of summer droughts are outweighed by growth benefits from access to groundwater under favorable growing conditions (Leuschner and Ellenberg, 2017). In addition, this indicates that sensitivity in terms of the strength of climate-growth correlations on its own is not a sufficient indicator of growth stress. Only in combination with the analysis of growth deviations under favorable and unfavorable conditions can this indicator be interpreted properly. If sensitivity of radial growth increases as a result of positive growth responses to favorable growing conditions, this should not be read as a negative sign, as has been done in many previous studies of climate-growth relationships (e.g., von Oheimb et al., 2014; Caminero et al., 2018).

In contrast to sites without water extraction, sensitivity of trees to drought at the groundwater extraction sites showed no particular trend with increasing stand age. The lower sensitivity of trees between 60 and 100 years old at the extraction sites, compared to trees of similar age growing at the wetter sites, might be a consequence of their lack of positive growth responses under favorable conditions (Figure 8). This lack of response in radial growth under favorable conditions could be a consequence of higher investment of $\mathrm{C}$ into the root system (e.g., Wang et al., 2015) or lower amounts of stored non-structural C. However, we have no quantitative information on rooting pattern and belowground biomass in relation to groundwater levels.

\section{Effect of Groundwater Regime on Temporal Development of Climate-Drought Relationships}

Moving correlation analyses revealed non-stationary relationships between annual growth of oak trees and short-term drought indices (SPEI 6) (Figures 9, 10 and Supplementary S5). Similar changes in climate-growth relationships over time for pedunculate and sessile oaks have been observed in several studies conducted in Central-Europe (e.g., Friedrichs et al., 2008, 2009; Mérian et al., 2011; Árvai et al., 2018). We observed a substantial decrease in the strength of drought-growth relationships for the 30-year long windows between 1920 and 1950 in comparison to the period before. Likewise, Friedrichs et al. (2008) reported a similar reduction of the relationship between growth and drought for exactly the same period for both pedunculate and sessile oaks in Central-West Germany. The observed reduced sensitivity of annual-growth to drought during this period demonstrates clearly the complexity when studying climate-growth relationships. Surprisingly, despite low precipitation and higher than average temperatures during this period, growth levels increased (Friedrichs et al., 2008). Following this period, trees growing at the extraction and upland sites demonstrated a greater growth sensitivity to drought, while no such effect was found for trees at sites without extraction.

The influence of summer drought on growth of oaks at the extraction sites increased following the beginning of groundwater extraction in all regions as indicated by the stronger climategrowth relationships over time. As we did not observe such an increase in strength of the relationship between summerdrought and growth at adjacent sites without groundwater extraction over the same period, the stronger climate-growth relationships at extraction sites can be regarded as a result of lowered groundwater tables. This increased sensitivity to summer drought was accompanied by overall lower growth levels compared to trees at sites without extraction over the period following the onset of groundwater extraction (Figure 3). Additionally, oak trees at the extraction sites had a lower ability to respond positively to years with favorable summer conditions (Figure 8). The differences observed in the response of trees to summer-drought between extraction and no extraction sites corroborate findings of Raney et al. (2016) and further support the idea that negative effects of elevated summer temperatures and reduced precipitation on tree-growth can be mitigated by access to groundwater. In contrast to our results for trees at lowland sites without extraction, we observed an increasing 
sensitivity of radial growth to summer drought for sessile oak trees at the drier uplands over the investigated period (Figures 9, 10 and Supplementary S.5). Our results are consistent with results of other studies, which report a stronger relationship between growth of sessile oaks and drought during recent decades compared to the beginning of the twentieth century (Friedrichs et al., 2008, 2009). It is very likely that the observed trends of increasing drought sensitivity in sessile oaks are indeed driven by decreases in summer precipitation that were observed in the region of Freiburg and Emmendingen but most importantly by increases in summer temperature, which were observed for all studied regions (Figure 4).

Several additional non-climatic factors can influence radial growth of trees, potentially affecting the climatic signal laid-down in tree-ring records. These include massive defoliation through periodical outbreaks of herbivorous insects (Büntgen et al., 2009; Black et al., 2016) and masting events that divert the available $\mathrm{C}$ from radial growth to seed production (Di Filippo et al., 2007; Genet et al., 2010; Hacket-Pain et al., 2015). The influence of such factors on climate-growth relationships could not be tested for the time periods examined here, although it might have explained some of the noise in our data.

\section{CONCLUSIONS}

In this study, we investigated the effects of groundwater extraction on climate-growth relationships for pedunculate and sessile oak trees covering a wide range of tree ages growing under differing groundwater regimes. The evidence presented in this study suggests that groundwater extraction impairs radial growth and increases growth sensitivity of trees to summer drought while access to groundwater appears to mitigate the negative effects of increasing summer water-deficits on tree growth. In future, floodplain forests will likely experience more stress from the combined effects of increasing groundwater extraction rates and more frequent and prolonged warm and dry conditions. Therefore, the location of groundwater extraction sites as well as the rates and timing of water extraction should be carefully

\section{REFERENCES}

Ahner, J., and Schmidt, M. (2011). "Modellierung der Einzelbaummortalität der Eiche unter besonderer Berücksichtigung von Grundwasserabsenkungen - Eine Untersuchung im Hessischen Ried," in Presented at the Sektion Ertragskunde Jahrestagung 2011. Cottbus, 157.

Árvai, M., Morgós, A., and Kern, Z. (2018). Growth-climate relations and the enhancement of drought signals in pedunculate oak (Quercus robur L.) treering chronology in Eastern Hungary. IForest Biogeosci. For. 11, 267-274. doi: 10.3832/ifor2348-011

Becker, M., and Lévy, G. (1986). Croissance radiale comparée de chênes adultes (Quercus robur L. et Q. petraea (Matt.) Liebl.) sur sol hydromorphe acide: effet du drainage. Acta Oecol. Oecol. Plant. 7, 121-143.

Bhuyan, U., Zang, C., and Menzel, A. (2017). Different responses of multispecies tree ring growth to various drought indices across Europe. Dendrochronologia 44, 1-8. doi: 10.1016/j.dendro.2017.02.002

Black, B. A., Griffin, D., van der Sleen, P., Wanamaker, A. D., Speer, J. H., Frank, D. C., et al. (2016). The value of crossdating to retain high-frequency variability, considered to ensure that tree vitality and ecosystem health are not impaired.

\section{DATA AVAILABILITY}

The datasets generated for this study are available on request to the corresponding author.

\section{AUTHOR CONTRIBUTIONS}

JB conceived the study. JS and JB acquired funding for the project. GS, JB, and JS designed the study. GS carried out data collection, performed the analysis and drafted the manuscript. All authors discussed and interpreted the results and contributed to the writing of the final manuscript.

\section{FUNDING}

This work was supported by the DRIeR project funded under the framework of the Water Research Network by the Ministry of Science, Research, and Arts of the German Federal State of Baden Wuerttemberg (AZ. 7532.21/2.1.6).

\section{ACKNOWLEDGMENTS}

The authors thank the forestry districts of the City of Freiburg, Emmendingen and Lampertheim for their support and excellent collaboration. We also like to thank Jan Geyer for his assistance in fieldwork and Dr. Willy Tegel for his valuable comments on the manuscript. The article processing charge was funded by the German Research Foundation (DFG) and the University of Freiburg in the funding programme Open Access Publishing.

\section{SUPPLEMENTARY MATERIAL}

The Supplementary Material for this article can be found online at: https://www.frontiersin.org/articles/10.3389/ffgc.2019. 00005/full\#supplementary-material climate signals, and extreme events in environmental proxies. Glob. Change Biol. 22, 2582-2595. doi: 10.1111/gcb.13256

Bovolo, C. I., Parkin, G., and Sophocleous, M. (2009). Groundwater resources, climate and vulnerability. Environ. Res. Lett. 4:035001. doi: $10.1088 / 1748-9326 / 4 / 3 / 035001$

Bunn, A. G. (2008). A dendrochronology program library in R (dplR). Dendrochronologia 26, 115-124. doi: 10.1016/j.dendro.2008.01.002

Bunn, A. G. (2010). Statistical and visual crossdating in R using the dplR library. Dendrochronologia 28, 251-258. doi: 10.1016/j.dendro.2009.12.001

Büntgen, U., Frank, D., Liebhold, A., Johnson, D., Carrer, M., Urbinati, C., et al. (2009). Three centuries of insect outbreaks across the European Alps. New Phytol. 182, 929-941. doi: 10.1111/j.1469-8137.2009.02825.x

Buras, A. (2017). A comment on the expressed population signal. Dendrochronologia 44, 130-132. doi: 10.1016/j.dendro.2017.03.005

Caminero, L., Génova, M., Camarero, J. J., and Sánchez-Salguero, R. (2018). Growth responses to climate and drought at the southernmost European limit of Mediterranean Pinus pinaster forests. Dendrochronologia 48, 20-29. doi: 10.1016/j.dendro.2018.01.006 
Cook, E. R., and Peters, K. (1981). The smoothing spline: a new approach to standardizing forest interior tree-ring width series for dendroclimatic studies. Tree Ring Bull. 41, 45-53.

Copenheaver, C. A., Crawford, C. J., and Fearer, T. M. (2011). Age-specific responses to climate identified in the growth of Quercus alba. Trees 25, 647-653. doi: 10.1007/s00468-011-0541-2

Cunningham, S. C., Thomson, J. R., Mac Nally, R., Read, J., and Baker, P. J. (2011). Groundwater change forecasts widespread forest dieback across an extensive floodplain system: groundwater change forecasts forest dieback. Freshw. Biol. 56, 1494-1508. doi: 10.1111/j.1365-2427.2011.02585.x

Day, M. E., Greenwood, M. S., and Diaz-Sala, C. (2002). Age- and size-related trends in woody plant shoot development: regulatory pathways and evidence for genetic control. Tree Physiol. 22, 507-513. doi: 10.1093/treephys/22.8.507

Di Filippo, A., Biondi, F., Cufar, K., de Luis, M., Grabner, M., Maugeri, M., et al. (2007). Bioclimatology of beech (Fagus sylvatica L.) in the Eastern Alps: spatial and altitudinal climatic signals identified through a tree-ring network. J. Biogeogr. 34, 1873-1892. doi: 10.1111/j.1365-2699.2007.01747.x

Dister, E., Gomer, D., Obrdlik, P., Petermann, P., and Schneider, E. (1990). Water mangement and ecological perspectives of the upper rhine's floodplains. Regul. Rivers Res. Manag. 5, 1-15.

Drobyshev, I., Niklasson, M., Eggertsson, O., Linderson, H., and Sonesson, K. (2008). Influence of annual weather on growth of pedunculate oak in southern Sweden. Ann. For. Sci. 65:512. doi: 10.1051/forest:2008033

Earman, S., and Dettinger, M. (2011). Potential impacts of climate change on groundwater resources - a global review. J. Water Clim. Change 2:213. doi: $10.2166 /$ wcc. 2011.034

Eaton, E., Caudullo, G., Oliveira, S., and de Rigo, D. (2016). "Quercus robur and Quercus petraea in Europe: distribution, habitat, usage and threats," in European Atlas of Forest Tree Species, eds J. San-Miguel-Ayanz, D. de Rigo, G. Caudullo, T. Houston Durrant, and A. Mauri (Luxembourg: Publications Office of the European Union), 160-163.

Fonti, P., Von Arx, G., García-González, I., Eilmann, B., Sass-Klaassen, U., Gärtner, H., et al. (2010). Studying global change through investigation of the plastic responses of xylem anatomy in tree rings. New Phytol. 185, 42-53. doi: 10.1111/j.1469-8137.2009.03030.x

Friedrichs, D. A., Büntgen, U., Frank, D. C., Esper, J., Neuwirth, B., and Löffler, J. (2008). Complex climate controls on 20th century oak growth in Central-West Germany. Tree Physiol. 29, 39-51. doi: 10.1093/treephys/tpn003

Friedrichs, D. A., Trouet, V., Büntgen, U., Frank, D. C., Esper, J., Neuwirth, B., et al. (2009). Species-specific climate sensitivity of tree growth in Central-West Germany. Trees 23, 729-739. doi: 10.1007/s00468-009-0315-2

Fritts, H. C. (1976). Tree Rings and Climate. London; New York, NY: Academic Press.

Führer, E. (1998). Oak Decline in Central Europe: A Synopsis of Hypotheses. Proceedings: Population Dynamics, and Integrated Management of Forest Defoliating Insects. USDA Forest Service General Technical Report NE-247 USDA. Washington, DC, 7-24.

Galiano, L., Martínez-Vilalta, J., and Lloret, F. (2011). Carbon reserves and canopy defoliation determine the recovery of Scots pine $4 \mathrm{yr}$ after a drought episode. New Phytol. 190, 750-759. doi: 10.1111/j.1469-8137.2010.03628.x

Genet, H., Bréda, N., and Dufrêne E. (2010). Age-related variation in carbon allocation at tree and stand scales in beech (Fagus sylvatica L.) and sessile oak (Quercus petraea (Matt.) Liebl.) using a chronosequence approach. Tree Physiol. 30, 177-192. doi: 10.1093/treephys/tpp105

González, I. G., and Eckstein, D. (2003). Climatic signal of earlywood vessels of oak on a maritime site. Tree Physiol. 23, 497-504. doi: 10.1093/treephys/23.7.497

Green, T. R., Taniguchi, M., Kooi, H., Gurdak, J. J., Allen, D. M., Hiscock, K. M., et al. (2011). Beneath the surface of global change: impacts of climate change on groundwater. J. Hydrol. 405, 532-560. doi: 10.1016/j.jhydrol.2011. 05.002

Hacket-Pain, A. J., Friend, A. D., Lageard, J. G., and Thomas, P. A. (2015). The influence of masting phenomenon on growth-climate relationships in trees: explaining the influence of previous summers' climate on ring width. Tree Physiol. 35, 319-330. doi: 10.1093/treephys/tpv007

Haneca, K., Cufar, K., and Beeckman, H. (2009). Oaks, tree-rings and wooden cultural heritage: a review of the main characteristics and applications of oak dendrochronology in Europe. J. Archaeol. Sci. 36, 1-11. doi: $10.1016 /$ j.jas.2008.07.005
Horner, G. J., Baker, P. J., Nally, R. M., Cunningham, S. C., Thomson, J. R., and Hamilton, F. (2009). Mortality of developing floodplain forests subjected to a drying climate and water extraction. Glob. Change Biol. 15, 2176-2186. doi: 10.1111/j.1365-2486.2009.01915.x

Hughes, F. M. R. (2003). The Flooded Forest: Guidance for Policy Makers and River Managers in Europe on the Restoration of Floodplain Forests. FLOBAR2, Department of Geography, University of Cambridge, Cambridge, UK.

Imada, S., Yamanaka, N., and Tamai, S. (2008). Water table depth affects Populus alba fine root growth and whole plant biomass. Funct. Ecol. 22, 1018-1026. doi: 10.1111/j.1365-2435.2008.01454.x

Kath, J., Reardon-Smith, K., Le Brocque, A. F., Dyer, F. J., Dafny, E., Fritz, L., et al. (2014). Groundwater decline and tree change in floodplain landscapes: identifying non-linear threshold responses in canopy condition. Glob. Ecol. Conserv. 2, 148-160. doi: 10.1016/j.gecco.2014.09.002

Kern, Z., Patkó, M., Kázmér, M., Fekete, J., Kele, S., and Pályi, Z. (2013). Multiple tree-ring proxies (earlywood width, latewood width and $\delta 13 \mathrm{C}$ ) from pedunculate oak (Quercus robur L.), Hungary. Quat. Int. 293, 257-267. doi: 10.1016/j.quaint.2012.05.037

Kløve, B., Ala-Aho, P., Bertrand, G., Gurdak, J. J., Kupfersberger, H., Kværner, J., et al. (2014). Climate change impacts on groundwater and dependent ecosystems. J. Hydrol. 518, 250-266. doi: 10.1016/j.jhydrol.2013.06.037

Konter, O., Büntgen, U., Carrer, M., Timonen, M., and Esper, J. (2016). Climate signal age effects in boreal tree-rings: lessons to be learned for paleoclimatic reconstructions. Quat. Sci. Rev. 142, 164-172. doi: 10.1016/j.quascirev.2016.04.020

Kozlowski, T. T. (2002). Physiological-ecological impacts of flooding on riparian forest ecosystems. Wetlands 22, 550-561. doi: 10.1672/02775212(2002)022[0550:PEIOFO]2.0.CO;2

LeMaitre, D. C., Scott, D. F., and Colvin, C. (1999). A review of information on interactions between vegetation and groundwater. Water SA 25, 137-152.

Leuschner, C., and Ellenberg, H. (2017). Ecology of Central European Forests. Cham: Springer International Publishing.

Levanic, T., Cater, M., and McDowell, N. G. (2011). Associations between growth, wood anatomy, carbon isotope discrimination and mortality in a Quercus robur forest. Tree Physiol. 31, 298-308. doi: 10.1093/treephys/tpq111

Mann, H. B. (1945). Nonparametric tests against trend. Econometrica 13:245 doi: $10.2307 / 1907187$

McLeod, A. I. (2011). Kendall: Kendall Rank Correlation and Mann-Kendall Trend Test. R package version 2.2. Available online at: http://cran.r-project.org/ package $=$ Kendall

Mérian, P., Bontemps, J.-D., Bergès, L., and Lebourgeois, F. (2011). Spatial variation and temporal instability in climate-growth relationships of sessile oak (Quercus petraea [Matt.] Liebl.) under temperate conditions. Plant Ecol. 212, 1855-1871. doi: 10.1007/s11258-011-9959-2

Naumburg, E., Mata-gonzalez, R., Hunter, R. G., Mclendon, T., and Martin, D. W. (2005). Phreatophytic vegetation and groundwater fluctuations: a review of current research and application of ecosystem response modeling with an emphasis on great basin vegetation. Environ. Manag. 35, 726-740. doi: 10.1007/s00267-004-0194-7

Oosterbaan, A., and Nabuurs, G. J. (1991). Relationships between oak decline and groundwater class in The Netherlands. Plant Soil 136, 87-93. doi: 10.1007/BF02465223

Orellana, F., Verma, P., Loheide, S. P., and Daly, E. (2012). Monitoring and modeling water-vegetation interactions in groundwater-dependent ecosystems. Rev. Geophys. 50:RG3003. doi: 10.1029/2011RG000383

Pohlert, T. (2018). Trend: Non-Parametric Trend Tests and Change-Point Detection. R package version, 1.1.1. Available online at: https:/cran.r-project. org/web/packages/trend/index.html

QGIS Development Team (2017). QGIS Geographic Information System. Open Source Geospatial Foundation Project. Available online at: http://qgis.osgeo.org

R Core Team (2017). R: A Language and Environment for Statistical Computing. Vienna: R Foundation for Statistical Computing.

Raney, P. A., Leopold, D. J., Dovciak, M., and Beier, C. M. (2016). Hydrologic position mediates sensitivity of tree growth to climate: groundwater subsidies provide a thermal buffer effect in wetlands. For. Ecol. Manag. 379, 70-80. doi: 10.1016/j.foreco.2016.08.004

Rita, A., Borghetti, M., Todaro, L., and Saracino, A. (2016). Interpreting the climatic effects on xylem functional traits in two mediterranean oak 
species: the role of extreme climatic events. Front. Plant Sci. 7:1126. doi: $10.3389 /$ fpls.2016.01126

Roloff, A. (2001). Baumkronen: Verständnis und Praktische Bedeutung eines komplexen Naturphänomens. Stuttgart: Ulmer.

Rozas, V. (2005). Dendrochronology of pedunculate oak (Quercus robur L.) in an old-growth pollarded woodland in northern Spain: tree-ring growth responses to climate. Ann. For. Sci. 62, 209-218. doi: 10.1051/forest:2005012

Rozas, V., DeSoto, L., and Olano, J. M. (2009). Sex-specific, age-dependent sensitivity of tree-ring growth to climate in the dioecious tree Juniperus thurifera. New Phytol. 182, 687-697. doi: 10.1111/j.1469-8137.2009. 02770.x

Ryan, M. G., Phillips, N., and Bond, B. J. (2006). The hydraulic limitation hypothesis revisited. Plant Cell Environ. 29, 367-381. doi: 10.1111/j.1365-3040.2005.01478.x

Sala, A., Woodruff, D. R., and Meinzer, F. C. (2012). Carbon dynamics in trees: feast or famine?. Tree Physiol. 32, 764-775. doi: 10.1093/treephys/tpr143

Schnitzler, A., Hale, B. W., and Alsum, E. (2005). Biodiversity of floodplain forests in Europe and eastern North America: a comparative study of the Rhine and Mississippi Valleys. Biodivers. Conserv. 14:97. doi: 10.1007/s10531-005-4056-2 Schweingruber, F. H. (1988). Tree Rings. Dordrecht: Springer.

Sen, P. K. (1968). Estimates of the regression coefficient based on Kendall's Tau. J. Am. Chem. Soc. 63, 1379-1389.

Silver, N. C., and Dunlap, P. W. (1987). Averaging correlation coefficients should fishers $\mathrm{z}$ transformation be used? J. Appl. Psychol. 72:146. doi: 10.1037/0021-9010.72.1.146

Sourcepole (2017). Quantum GIS OpenLayers Plugin. Available online at: http:// plugins.qgis.org/plugins/openlayers_plugin

Speer, J. H. (2001). Oak Mast History from Dendrochronology: A New Technique Demonstrated in the Southern Appalachian Region. Dissertation, University of Tennessee, Knoxville, TN.

Speer, J. H. (2010). Fundamentals of Tree-Ring Research. Tucson, AZ: University of Arizona Press.

Stojanović, D. B., Levanič, T., Matović, B., and Orlović, S. (2015). Growth decrease and mortality of oak floodplain forests as a response to change of water regime and climate. Eur. J. For. Res. 134, 555-567. doi: 10.1007/s10342015-0871-5

Taylor, R. G., Scanlon, B., Döll, P., Rodell, M., van Beek, R., Wada, Y., et al. (2013). Ground water and climate change. Nat. Clim. Change 3, 322-329. doi: $10.1038 /$ nclimate1744

Thomas, F. M. (2008). Recent advances in cause-effect research on oak decline in Europe. CAB Rev. Perspect. Agric. Vet. Sci. Nutr. Nat. Resour. 3, 1-12. doi: 10.1079/PAVSNNR20083037

Thomas, F. M., Blank, R., and Hartmann, G. (2002). Abiotic and biotic factors and their interactions as causes of oak decline in Central Europe. For. Pathol. 32, 277-307. doi: 10.1046/j.1439-0329.2002.00291.x

Thomas, F. M., and Hartmann, G. (1998). Tree rooting patterns and soil water relations of healthy and damaged stands of mature oak (Quercus robur L. and Quercus petraea [Matt.] Liebl.). Plant Soil 203, 145-158. doi: 10.1023/A:1004305410905

van Dijk, G. M., Marteijn, E. C. L., and Schulte-Wülwer-Leidig, A. (1995). Ecological rehabilitation of the River Rhine: plans, progress and perspectives. Regul. Rivers Res. Manag. 11, 377-388. doi: 10.1002/rrr.34501 10311

Vicente-Serrano, S. M., Beguería, S., and López-Moreno, J. I. (2010). A multiscalar drought index sensitive to global warming: the standardized precipitation evapotranspiration index. J. Clim. 23, 1696-1718. doi: 10.1175/20 09JCLI2909.1

Vicente-Serrano, S. M., Beguería, S., Lorenzo-Lacruz, J., Camarero, J. J., LópezMoreno, J. I., Azorin-Molina, C., et al. (2012). Performance of drought indices for ecological, agricultural, and hydrological applications. Earth Interact. 16, 1-27. doi: 10.1175/2012EI000434.1

Vicente-Serrano, S. M., Gouveia, C., Camarero, J. J., Beguería, S., Trigo, R., López-Moreno, J. I., et al. (2013). Response of vegetation to drought timescales across global land biomes. Proc. Natl. Acad. Sci. U.S.A. 110, 52-57. doi: $10.1073 /$ pnas. 1207068110

Voelker, S. L. (2011). “Age-dependent changes in environmental influences on tree growth and their implications for forest responses to climate change," in Sizeand Age-Related Changes in Tree Structure and Function, eds F. C. Meinzer, B. Lachenbruch, and T. E. Dawson (Dordrecht: Springer), 455-479.

von Oheimb, G., Härdtle, W., Eckstein, D., Engelke, H.-H., Hehnke, T., Wagner, B., et al. (2014). Does forest continuity enhance the resilience of trees to environmental change? PLoS ONE 9:e113507. doi: 10.1371/journal.pone.0113507

Wang, L., Zhao, C., Li, J., Liu, Z., and Wang, J. (2015). Root plasticity of populus euphratica seedlings in response to different water table depths and contrasting sediment types. PLoS ONE 10:e0118691. doi: 10.1371/journal.pone.0118691

Wigley, T. M., Briffa, K. R., and Jones, P. D. (1984). On the average value of correlated time series, with applications in dendroclimatology and hydrometeorology. J. Clim. Appl. Meteorol. 23, 201-213. doi: 10.1175/1520-0450(1984)023<0201:OTAVOC > 2.0.CO;2

Zang, C., and Biondi, F. (2015). treeclim: an R package for the numerical calibration of proxy-climate relationships. Ecography 38, 431-436. doi: 10.1111/ecog.01335

Zhang, S. Y. (1997). Variations and correlations of various ring width and ring density features in European oak: implications in dendroclimatology. Wood Sci. Technol. 31, 63-72. doi: 10.1007/BF00705701

Zolfaghar, S., Villalobos-Vega, R., Cleverly, J., Zeppel, M., Rumman, R., and Eamus, D. (2014). The influence of depth-to-groundwater on structure and productivity of Eucalyptus woodlands. Aust. J. Bot. 62, 428-437. doi: 10.1071/BT14139

Conflict of Interest Statement: The authors declare that the research was conducted in the absence of any commercial or financial relationships that could be construed as a potential conflict of interest.

Copyright (c) 2019 Skiadaresis, Schwarz and Bauhus. This is an open-access article distributed under the terms of the Creative Commons Attribution License (CC BY). The use, distribution or reproduction in other forums is permitted, provided the original author(s) and the copyright owner(s) are credited and that the original publication in this journal is cited, in accordance with accepted academic practice. No use, distribution or reproduction is permitted which does not comply with these terms. 